DOI https://doi.org/10.18551/rjoas.2018-06.10

\title{
THE EFFECT OF ENVIRONMENTAL KNOWLEDGE, GREEN ADVERTISING AND ENVIRONMENTAL ATTITUDE TOWARD GREEN PURCHASE INTENTION
}

\author{
Pratiwi Ni Putu Deviary Kusuma* \\ Master's Program in Management, University of Mataram, Indonesia \\ Sulhaini, Rinuastuti Baiq Handayani \\ Lecturer of Master's Program in Management, University of Mataram, Indonesia \\ *E-mail: putudeviary@gmail.com
}

\begin{abstract}
This study aims to determine the effect of environmental knowledge and green advertising on environmental attitudes and green purchase intention, and the effect of environmental attitude toward green purchase intention of Starbucks consumer in Mataram City. The research method used is quantitative with causal associative approach. Data collection using questionnaires distributed to 170 Starbucks consumers in Lombok Epicentrum Mall with convenience sampling technique. Analysis method used Path analysis. The research findings show that environmental knowledge and green advertising have a positive and significant effect on environmental attitude and green purchase intention; and environmental attitude have a positive and significant effect on green purchase intention. Increased public awareness of environmental knowledge and positive attitudes increases the chance of Starbucks to create environmentally-based products.
\end{abstract}

\section{KEY WORDS}

Environmental knowledge, green advertising, environmental attitude, purchase intention.

Current environmental issues make consumers more sensitive. In terms of needs, there is an attempt to stop and reverse the negative effects of human behavior on the environment (Leonidou et al., 2010). Consumers are increasingly aware of excessive behavior in used of resources can affect the environment (Henning \& Karlsson, 2011), so consumer give more attention to environmental impacts by purchasing eco-friendly goods or services (Dagher et al., 2015). Consumers who prefer products eco-friendly and their daily consumption behavior consider the effects on the environment known as green consumer. These consumers avoid products that could endanger health, harm the environment, use materials derived from protected species, and cause hazardous waste (Ali \& Ahmad, 2012). This makes companies adapted to environmental concerns gaining popularity over the last few decades (Ali \& Ahmad, 2012). Companies are encouraged to increase community knowledge and awareness of the environment by developing programs that provide solutions to environmental problems (Rini et al., 2017), where some modern companies are protecting the environment as a key idea for implementing friendly marketing strategies environment (Wulandari et al., 2015).

Young consumers are potential customers who can initiate a change from ignorance to environmental issues to care and think about the impact on the environment. Lee (2009) in his study suggested that international green marketers consider teenagers as one of the potential market targets. Young consumers have purchasing power, are able to influence the buying decisions of the people around them, and are open to new things and innovative ideas. This study begins with previous research that has been done on factors that affect green purchase intention, one of which research conducted by Delafrooz et al. (2014) states that one of the factors affecting green purchase intention is green advertising. Study conducted by Safe et al., (2012) states that environmental knowledge and attitudes are environmental factors that affects the intention of purchasing green products. 
The company has contributed to fulfilling the green needs of consumers with more environmental responsibility, seen through eco-friendly manufacturing processes and green promotions (D'Souza \& Taghian, 2005). Green advertising used by marketers to implement promotional activities as an effort to attract the public attention to be more aware of the go green activities. Green advertising helps companies to disseminate information and knowledge to consumers who are not conscious of eco-friendly products and features (Ahuja, 2015). Ginting and Ekawati (2016) states that an environmentally conscious person tends to buy and use eco-friendly products. Its based on factors such as knowledge of the environment, attitudes that view the importance of the environment as well as advertisements about eco-friendly products. Instead, Leonidou et al. (2010) states that a person with an environmental attitude can act in an eco-friendly manner and does not have to engage in green purchasing behavior. With the phenomenon has described and there are inconsistent results of research related the influence of environmental knowledge, green advertising and environmental attitudes toward green purchase intention, it is necessary to conduct further research using Starbucks consumer in Mataram City.

\section{LITERATURE REVIEW}

Consumer Attitude. Theory of reasoned action (TRA) proposed by Azjen and Fishbein (1980), states that if the person can decide at will to perform or not perform the behavior depend on the intention possessed by that person. Azjen and Fishbein (1980) suggested that intentions to perform or not to do certain behaviors is influenced by two basic determinants, the first relates to attitudes (attitude toward behavior) and the other related to social influences ie subjective norms. Theory of Planned Behavior (TPB) is a further development of the Theory of reasoned action (TRA) proposed by Azjen and Fishbein (1991) by adding constructs not yet in the TRA i.e perceived behavioral control. TPB is used to explain and predict both behavioral intentions and actual behavior, and is often used in various research on behavior. Usually TPB is used as an intervening variable to explain a person's intention which then explains the person's behavior.

The current study uses Theory of Reasoned Action as an theoretical basis for explaining the theoretical framework used in this study consisting of environmental knowledge, green advertising and environmental attitudes to explain behavioral intention purchase of green products.

Environmental Knowledge. Knowledge is information that is known or realized by someone who is stored in memory. Knowledge is a relevant and important construct that affects how consumers collect and organize information on how much information is used for decision making and how consumers evaluate products and services (Syahbandi, 2012). Knowledge of the environment is the level of public understanding as a potential consumer of green products on issues of long-term health and welfare importance, including issues relating to the negative impacts of harmful chemicals, pollutants, greenhouse gases, packaging product recycling, and other issues potentially affecting positive attitudes toward green products (Ali et al., 2011; Haryanto \& Budiman, 2014). While Chen (2013) explains that environmental knowledge is understood as a series of ecological knowledge held by a person related to environmental topics, such as what can be done to help protect the environment by committing to their behavior to purchase green products (Lee, 2010 ).

According to research conducted by Gan et al., (cited by Chen, 2013), environmental knowledge develops in two forms, namely the consumer must be educated to be able to understand the impact of a product on the environment and consumer knowledge in the product itself is produced in an eco-friendly manner. According to Julina (2013), knowledge of environmental issues can affect one's attitude. Barber et al., (2010) revealed that one of the functions of environmental knowledge is to help maintain a strong environmental stance. Research conducted by Noor et al. (2012) found that environmental knowledge positively affects attitudes. While research conducted by Aman et al. (2012) reject the influence of environmental knowledge on attitudes. In a study by Levine and Strube (2012) found that environmental knowledge was not significantly related to attitudes. 
Environmental knowledge not only affect one's attitude toward the environment, such as research conducted by Aman et al. (2012) found an influence between environmental knowledge on green purchase intentions or eco-friendly products. Similarly, the results of a study by Mei et al., (2012) which shows that environmental knowledge affects the intention to buy eco-friendly products to consumers. However, these results are in contrast to research conducted by Henning and Karlsson (2011) who rejected the hypothesis that there is a positive influence between environmental knowledge on the intention to buy eco-friendly products. attitude.

$\mathrm{H}_{1}$ : Environmental knowledge has a positive and significant effect on environmental intention.

$\mathrm{H}_{2}$ : Environmental knowledge has a positive and significant effect on green purchase

Green Advertising. According to Tjiptono (2005), advertising is one of the most widely used promotional forms of enterprise in the form of indirect communication based on information about the superiority of a product, arranged in such a way that gives rise to a sense of fun that will change a person's mind to make a purchase. Advertising is aimed at influencing affection and consumer cognition, evaluation, feelings, knowledge, meaning, beliefs, attitudes, and images related to products and brands (Peter \& Olson, 2000). Marketing communication through advertising promotion activities is one strategy in introducing or explaining the marketed products. Environmental advertisment or can be referred to as green advertising provides information about eco-friendly products from a product or service in order to attract consumers to buy or use products that are friendly to the environment (Prastiyo, 2016). Consumers will be willing to pay more for green products, so to take advantage of these emerging opportunities, advertisers need to improve their understanding of how consumers respond to environmental advertising claims. Such an understanding will give advertisers valuable insights to improve the effectiveness of their communications in environmental advertisements (Chan, 2004).

Advertising is used by the company as an indirect communication that provides information about the benefits of a product so it can cause a person's desire to make a purchase. Research conducted by Delafrooz et al. (2014) found that green advertising is an action to influence consumer attitudes to buy environmentally friendly products and by encouraging them to buy products that do not harm the environment. Green advertising not only affects consumer attitudes toward the environment, research by Zhu (2013) finds that the credibility of claims in green advertisements has an important role in influencing consumer purchase intentions of green products. It is also supported by research conducted by Ahmad et al. (2010) which shows that environmental advertising has an impact on consumer purchase intention to green product. While Rahbar and Wahid (2011) found that green advertising helps consumers make purchasing decisions, but does not affect consumer behavior in purchasing green products.

$\mathrm{H}_{3}$ : Green advertising has a positive and significant effect on environmental attitude.

$\mathrm{H}_{4}$ : Green advertising has a positive and significant effect on green purchase intention.

Environmental Attitude. Attitudes usually have a major role in shaping behavior that is the result of previous experience (Engel et al., 1994). Attitude is an expression of feelings of likes or dislikes from someone who can be reflected on a particular object (Rini et al., 2017). According to Lee (2009), environmental attitude is a cognitive assessment of the value of environmental protection. Environmental attitude is a tendency that occurs to a person who can be formed or studied when responding consistently to environmental circumstances in the form of likes (positive) or dislike (negative) based on three things, i.e: perception and knowledge about the problems of the environment (a component of cognitive ), feelings or emotions that appear to the environment (an affective component), and a tendency to behave or act on the environment (a conative component) (Sumarsono \& Giyatno, 2012). Research conducted by Paco and Raposo (2009) in Portugal revealed that consumers understand about the environment, support policies to improve the environment, although their concerns do not turn into an action. 
Green Purchase Intention. Before a person takes action using a product or service, there is an inherent mental activity known as intention. According to Junaidi (cited by Laksmi \& Wardana, 2015), purchase intentions are consumer attitudes towards products that are composed of consumer confidence in the brand and brand evaluation, so comes the intention to buy. Consumers should have a prior desire for a product before deciding to actually buy the product. Green purchase intention in research by Karatu \& Mat (2014) is described as the possibility and willingness of individuals to give preference to brand products / services that have environmentally-friendly characteristics in their purchasing decisions. While Rashid (2009) defines green buying intentions as the probability and willingness of a person to give preference to green products over conventional products in consideration of their purchase. However, research conducted by Morel and Kwakye (2012) states that not fully attitudes affect the intention of buying environmentally friendly products. Someone with environmental attitudes can act in a way that is friendly to the environment, but does not have to engage in green purchasing behavior, which is the result of the development of green attitudes (Leonidou et al., 2010). intention.

$\mathrm{H}_{5}$ : Environmental attitude has a positive and significant effect on green purchase

\section{METHODS OF RESEARCH}

The method of this study used is quantitative that is causal associative, it aims to know the influence between variables: environmental knowledge, green advertising and environmental attitude toward green purchase intention. Data collecting through questionnaires distributed to 170 respondents consumer of Starbucks in Lombok Epicentrum Mall with convenience sampling technique. The questionnaires are distributed as many as 170 questionnaires and then all the questionnaires processed by using Path analysis to get the results of respondents answers. The variables found in this study are the environmental knowledge variables measured by using indicators developed by (Lee, 2010; Mei et al., 2012; Suryandari et al., 2016), the green advertising variable is measured using indicators developed by (Haytko \& Matulich, 2008; Herman et al., 2017), environmental attitude variables were measured using indicators developed by (Lee, 2009; Suryandari et al., 2016) and green purchase variables intention using indicators developed by (Ginting \& Ekawati, 2016; Mei et al., 2012). Weighting on each variable using a 7 level scale. Each number is from 1 (low) and 7 (highest). The hypothesis model in this study are:

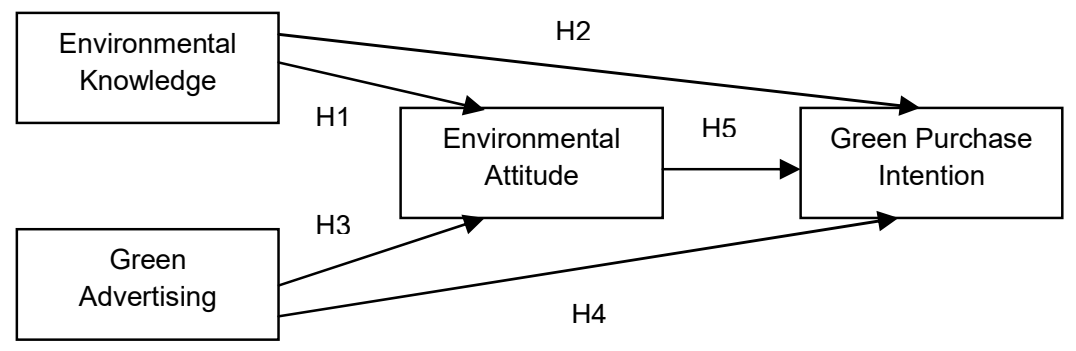

Figure 1 - Hypothesis Model

\section{RESULTS AND DISCUSSION}

Amount respondents that have been collected in this study is 170 respondents. From the results of questionnaires spread each respondent has a different characteristic. Hence, groupings are characterized by gender, age, occupation, and income.

Based on table 1 shows the characteristics of respondents by gender more dominated by female with age range $20-29$ years, have job as private employee and most have income equal to IDR 2,500,500 - IDR 5,000,000. 
Before hypothesis testing, validity and reliability testing of the research instrument was performed. Validity test is used to measure validity or invalidity of a questionnaire (Ghozali, 2005) and reliability test used to measure reliabel or not the research instrument. The validity of this study was measured by Corrected Item-Total Correlation, an acceptable value being $\geq$ 0.3 (Pallant, 2005). The result of validity test of research instrument shows that r-count of all items of variable greater than 0.30 is valid so it is feasible to be used as data collecting tool. Reliability in this study measured by Cronbach Alpha coefficient, acceptable values were $\geq$ 0.70 (Hair, Black, Babin, \& Anderson, 2010). The instrument reliability test results show that all items in the research variable are reliable because Cronbach's Alpha is above 0.70.

Table 1 - Characteristic of respondents

\begin{tabular}{|l|l|c|c|}
\hline \multicolumn{1}{|c|}{ Respondent } & Amount & Percentage (\%) \\
\hline \multirow{5}{*}{ Gender } & Male & 61 & $36 \%$ \\
\cline { 2 - 4 } & Female & 109 & $64 \%$ \\
\cline { 2 - 4 } & Total & 170 & 100 \\
\hline \multirow{5}{*}{ Age (years) } & $<20$ years & 4 & $2 \%$ \\
\cline { 2 - 4 } & $20-29$ years & 127 & $75 \%$ \\
\cline { 2 - 4 } & $30-39$ years & 26 & $15 \%$ \\
\cline { 2 - 4 } & $40-49$ years & 9 & $5 \%$ \\
\cline { 2 - 4 } & $\geq 50$ years & 4 & $2 \%$ \\
\cline { 2 - 4 } & Total & 170 & 100 \\
\hline \multirow{5}{*}{ Occupation } & Civil Servants (PNS) & 27 & $16 \%$ \\
\cline { 2 - 4 } & Private employees & 55 & $32 \%$ \\
\cline { 2 - 4 } & Entrepreneur & 19 & $11 \%$ \\
\cline { 2 - 4 } & Students & 43 & $25 \%$ \\
\cline { 2 - 4 } & Others... & 26 & $15 \%$ \\
\cline { 2 - 4 } & Total & 170 & 100 \\
\hline & $<$ IDR 1.000.000 & 52 & $31 \%$ \\
\cline { 2 - 4 } & IDR 1.000.000 - IDR 2.500.000 & 41 & $24 \%$ \\
\cline { 2 - 4 } & IDR 2.500.500 - IDR 5.000.000 & 60 & $35 \%$ \\
\cline { 2 - 4 } & $>$ IDR 5.000.000 & 17 & $10 \%$ \\
\cline { 2 - 4 } & & 170 & 100 \\
\hline
\end{tabular}

Source: data questionnaire.

Normality test is used to test whether the regression model has a normal distribution or not (Ghozali, 2013). In this study, the normality test using Kolmogorov-Smirnov (1-sample K$S$ ) with decision making when p-value $>0.05$, then the data is normally distributed (Ghozali, 2013). Based on the normality test using Kolmogorov-Smirnov (1-sample K-S) obtained the following results:

Table 2 - One-Sample Kolmogorov-Smirnov Test

\begin{tabular}{|c|c|c|c|c|}
\hline- & $\begin{array}{c}\text { Environmental } \\
\text { Knowledge }\end{array}$ & $\begin{array}{c}\text { Green } \\
\text { Advertising }\end{array}$ & $\begin{array}{c}\text { Environmental } \\
\text { Attitude }\end{array}$ & $\begin{array}{c}\text { Green Purchase } \\
\text { Intention }\end{array}$ \\
\hline $\mathrm{N}$ & 170 & 170 & 170 & 170 \\
\hline $\begin{array}{c}\text { Kolmogorov- } \\
\text { Smirnov Z }\end{array}$ & 1.117 & 1.111 & .899 & 1.324 \\
\hline $\begin{array}{c}\text { Asymp. Sig. (2- } \\
\text { tailed) }\end{array}$ & .165 & .169 & .394 & .060 \\
\hline
\end{tabular}

Source: path analysis.

From the results in the One-Sample Kolmogorov-Smirnov table, Asymp column. Sig. shows the significance value for environmental knowledge, green advertising, environmental attitude, and green purchase intention greater than 0.05 it can be concluded that all variables are normally distributed. Number on column Kolmogorov-Smirnov Z shows the smaller the value then more normal data distribution.

Data analysis technique used is path analysis. Path analysis technique is used to analyze the causal relationships between variables with the aim to knowing the direct and 
indirect effect of simultaneously or independently of several exogenous variables to endogenous variables (Riduwan \& Kuncoro, 2012).

Table 3 - Result of Path analysis

\begin{tabular}{|c|c|c|c|c|c|c|c|}
\hline \multicolumn{4}{|c|}{ Hypothesis } & \multirow{2}{*}{$\begin{array}{c}\begin{array}{c}\mathrm{R} \\
\text { Square }\end{array} \\
.780\end{array}$} & \multirow{2}{*}{$\begin{array}{c}\begin{array}{c}\text { Standardized } \\
\text { Coefficients } \\
\text { Beta }\end{array} \\
.883\end{array}$} & \multirow{2}{*}{$\begin{array}{c}\begin{array}{c}\mathrm{t}- \\
\text { statistic }\end{array} \\
24,411\end{array}$} & \multirow{2}{*}{$\begin{array}{l}\text { Conclusion } \\
\text { Significant }\end{array}$} \\
\hline $\mathrm{H} 1$ & $\begin{array}{l}\text { Environmental } \\
\text { knowledge }\end{array}$ & $\rightarrow$ & $\begin{array}{l}\text { Environmental } \\
\text { attitude }\end{array}$ & & & & \\
\hline $\mathrm{H} 2$ & $\begin{array}{l}\text { Environmental } \\
\text { knowledge }\end{array}$ & & $\begin{array}{c}\text { Green purchase } \\
\text { intention }\end{array}$ & .203 & .451 & 6,541 & Significant \\
\hline $\mathrm{H} 3$ & Green advertising & $\rightarrow$ & $\begin{array}{l}\text { Environmental } \\
\text { attitude }\end{array}$ & .342 & .584 & 9,335 & Significant \\
\hline $\mathrm{H} 4$ & Green advertising & $\rightarrow$ & $\begin{array}{c}\text { Green purchase } \\
\text { intention }\end{array}$ & .388 & .623 & 10,317 & Significant \\
\hline $\mathrm{H} 5$ & $\begin{array}{l}\text { Environmental } \\
\text { attitude }\end{array}$ & $\rightarrow$ & $\begin{array}{c}\text { Green purchase } \\
\text { intention }\end{array}$ & .169 & .411 & 5,849 & Significant \\
\hline
\end{tabular}

Source: result from Path analysis.

${ }^{*}$ All significan at $p>0.000$.

The results of this study showed that environmental knowledge has a positive and significant effect on environmental attitude, which means hypothesis 1 is accepted. Knowledge of the environment that consumers have rightly influences their attitudes toward the environment. The results of this study support the research conducted by Noor et al. (2012) who found that green product consumers have an environmental knowledge that positively affects attitudes. The consumer's knowledge of the environment helps the consumer's thinking process to become a belief in shaping and expressing their attitudes toward the environment. Knowledge as a very important base for the formation of a person's actions because someone will act in accordance with the knowledge it has.

The results showed that environmental knowledge significantly and positively affected on green purchase intention, which means hypothesis 2 is accepted. The results show that the consumer's environmental knowledge can increase their green purchase intentions. The current findings support the results study conducted by Aman et al. (2012) that there is an influence or relationship between environmental knowledge to green purchase intention. Information on environmental issues and the importance of environmental sustainability of consumers have an effect on consumer purchase behavior. Consumers have an interest in products that do not have a negative impact on the environment, so consumers have the intention to make purchases of products that are eco-friendly.

The results showed that green advertising has a positive and significant on environmental attitude, whisch means hypothesis 3 is accepted. The results show that green advertising has the potential to influence consumer awareness to choose and use green products. The results of this study are in line with Delafrooz et al. (2014) that green advertising have a significant effect on consumer purchase behavior. Through green advertising, Starbucks provides information to its consumers about its eco-friendly products and programs so that consumers can know that Starbucks is a company that supports ecofriendly.

The result showed that green advertising significant and positive effect toward green purchase intention at Starbuck, Lombok Epicentrum Mall. Hence hypothesis 4 is accepted. These results suggest that green advertising positively affects green purchase intentions. In line with the results of a study by Zhu (2013), that the credibility of claims in green advertising has an important role in influencing consumer purchase intentions of green products. The strong intention of consumers to use green products is a positive attitude toward green advertising. Starbucks engages in advertising by linking products offered to the environment, lifestyle, and company image that care about the environment. Starbucks uses advertisers to inform consumers, persuade, and remind customers that Starbucks invites them to engage in Starbucks environmental actions or environmental protection programs so that consumers 
will have the intention of buying that will ultimately be motivated to make a purchase decision.

The results of this study indicated that environmental attitude significant and positive effect toward green purchase intention, then hypothesis 5 is accepted. The results of this study indicate that the more consumers have a pro-environment attitude then the greater the intention of consumers to buy eco-friendly products. This finding is in line with study conducted by Aman et al. (2012) and Lee (2009) that there is a positive relationship between attitudes toward the environment and green purchase intentions. Consumer attitudes towards the environment very positively. Consumers begin to feel the existence of a need for eco-friendly products so that consumers trying to find information about products that are eco-friendly. Once the information is gathered, it will face a variety of alternative products that claim eco-friendly choices so that individuals must identify and evaluate alternative choices to avoid the risk of errors in the purchase. After an evaluation of the product, appear green purchase intentions as a form of konative plan or the desire of consumers to obtain products that are eco-friendly. In accordance with Peter and Olson (2013) that attitude is a thorough evaluation of a person on a concept. From the results of these evaluations will appear intention to make a purchase product.

Table 4 - Indirect Effect

\begin{tabular}{|c|c|c|}
\hline \multirow{2}{*}{ Variable effect } & \multicolumn{2}{|c|}{ Causal effect } \\
\cline { 2 - 3 } & Direct & Indirect \\
\hline$X_{1} \rightarrow X_{3}$ & 0,883 & - \\
\hline$X_{1} \rightarrow Y$ & 0,451 & $0,883 \times 0,411=0,362$ \\
\hline$X_{1} \rightarrow Y \rightarrow X_{3}$ & - & - \\
\hline$X_{2} \rightarrow X_{3}$ & 0,584 & - \\
\hline$X_{2} \rightarrow Y$ & 0,623 & $0,584 \times 0,411=0,240$ \\
\hline$X_{2} \rightarrow Y \rightarrow X_{3}$ & - & - \\
\hline$X_{3} \rightarrow Y$ & 0,411 & \\
\hline
\end{tabular}

Source: indirect effect result.

The comparison of indirect effect of environmental knowledge to green purchase intention through environmental attitude is obtained result $0,362(<0,833)$ bigger than result of direct influence of environmental knowledge to green purchase intention so it can be stated that environmental attitude function not fully in mediate. This means that environmental knowledge is able to significantly affect green purchase intention without going through an environmental attitude. The consumer's knowledge of the environment helps the consumer's thinking process to become a belief in shaping and expressing their attitudes toward the environment. The expressions of these respondents concerns arise because they feel they need to protect the environment from damage, as revealed by Chen and Chai (2010) have pointed out that environmental attitudes are rooted in ones selfconcept and the extent to which an individual sees itself as part of the environment. Consumers' positive attitude toward the environment is then expressed in their consumption behavior. In consumption behavior, before they decide which products will be purchased consumers will have the intention first. As a form of their experiments on their environmental knowledge and high environmental attitudes, consumers will be more concerned with products that have eco-friendly claims compared to conventional products. Rashid (2009) defines green purchase intentions as the probability and willingness of a person to preference for green products over conventional products in consideration of their purchase. The findings of this study are also supported by Noor et al. (2012) who also get the result that a deep level of knowledge can affect a persons attitude, it will also have an impact on the purchasing intention.

The comparison of indirect effect of green advertising on green purchase intention through environmental attitude obtained result 0,240 $(<0,584)$ bigger than result of direct influence of green advertising to green purchase intention so that can be stated that environmental attitude function not full mediate. 


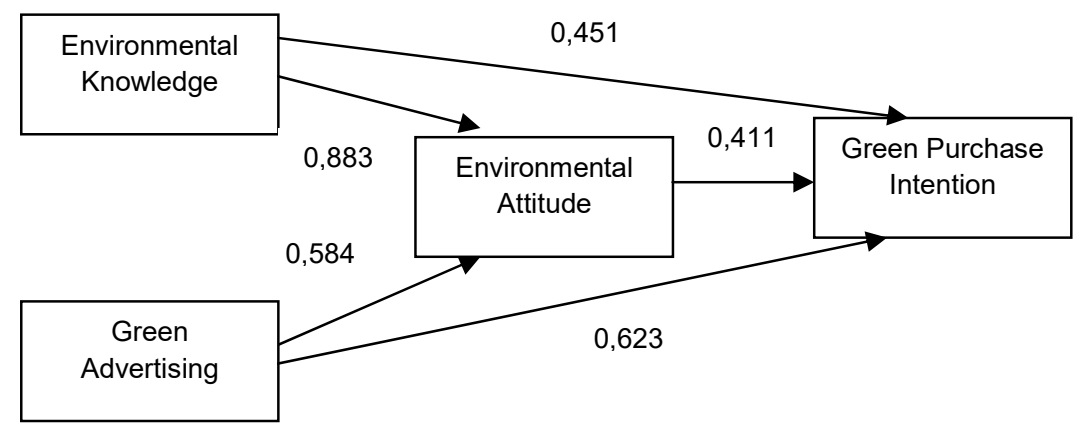

Figure 2 - Path analysis model

This means that green advertising can significantly affect green purchase intention without going through environmental attitude. Advertising that contain environmental claims convey their message more deeply by discussing the relationship between products and the environment (Leonidou, Leonidou, Palihawadana, \& Hultman, 2011), so that will affect the environmental attitudes of consumers in terms of affective advertising makes consumers evaluate information and express it positively that eco-friendly is essential to survival; and in terms of konative that advertising have an effect on consumers, they will take action that can protect the environment from damage. The environmental attitudes of the consumer also have an impact on green purchase intention. Green advertising affects consumers in terms of affective, so consumers assume important preservation of the environment and will bring the intention to buy products that are eco-friendly.

\section{CONCLUSION}

The theoretical implications of this study are that environmental knowledge and green advertising can positively and significantly affect environmental attitudes and green purchase intentions, as well as environmental attitudes can positively and significantly affect the intention of purchasing eco-friendly products from Starbucks. These findings also reinforce previous studies using Theory of Reasoned Action by Azjen and Fishbein (1980), where attitudes do have a degree of mediating effect on the relationship between environmental knowledge and green advertising on green buying intentions. In the current study, environmental attitudes are found to mediate the relationship between environmental knowledge and green advertising to green purchase intentions among Starbucks consumers of Mataram city.

Managerial implications in this study are useful for the company to deepen the importance of environmental knowledge owned by consumers and green advertisements in determining the attitude and intention to buy green products. Consumers have a positive knowledge and attitude towards the environment, shown by the knowledge of how to preserve the environment in daily activities which then leads to a positive attitude to the environment in doing things that can protect the environment. Mataram community knowledge about Starbucks that supports environmental friendliness and products and programs from Starbuck is still low. Starbucks has earth day programs and earth-saving events by providing discounts to tumbler users on specific dates of each month. In addition to these programs, companies should organize events that are directly related to the theme of the environment such as planting tree activities, holding seminars that educate the public and for consumers to be more aware of the existence of Starbucks products that support environmental friendliness. With the implementation of events related to the company's environment can also make consumer confidence increases.

The suggestion of this study is the high environmental knowledge and positive environmental attitude from consumers can be segmentation for Starbucks. Starbucks needs to give consumers more insight into the knowledge related to the dangers of using plastics and recycled products. This has been done by Starbucks through the green movement on the importance of environmental protection through small things like recycling and reducing 
the use of plastics for life. Companies should be continued to intensively green advertising, not only through social media but also try to use mass media such as newspapers and the use of brochures and pamphlets. If only doing advertising through social media then only the younger generation who hit the target.

For academics: future studies can investigate companies and other products that have eco-friendly claims. Researchers can then consider other variables related to green purchase intentions such as price, trust for eco-friendly products, corporate social responsibility (CSR) to the environment, adding moderate variables such as gender, and can do research using Theory of Reasoned Action (TRA) and Theory of Planned Behavior (TPB) toward green purchase intentions.

The limitation of this study is the short period of observation and only limited to environmental knowledge, green advertising and environmental attitude toward green purchase intention in the future is expected to be able to study and expand the scope of its research by considering other factors that can affect green purchase intention. The scope of this study is very limited and is only done to visitors of Lombok Epicentrum Mall, so the results of this study can not generalized to other consumers in a wider area. The research is only done on Starbucks products, not on green products in general or comparing existing green products with others. This data of study is taken in a certain time (cross section), is expected in the future can use time series data to produce better research.

\section{REFERENCES}

1. Ahmad, H., Ahmad, K., \& Shah, I. A. (2010). Factors in Environmental Advertising Influencing Consumer's. European Journal of Scientific Research, 48, 217-226.

2. Ahuja, K. (2015). A Study of Green Advertising and Its Impact on Consumer Purchase Intention. International Journal of Applied Research, 1(7), 39- 43.

3. Ali, A., \& Ahmad, I. (2012). Environment Friendly Products: Factors that Influence the Green Purchase Intentions of Pakistani Consumers. Pak. J. Eng. Technol.Sci, 2 (1), 84117.

4. Ali, A., Khan, A. A., \& Ahmed, I. (2011). Determinants of Pakistani Consumers' Green Purchase Behavior: Some Insights from a Developing Country. International Journal of Business and Social Science, 2 (3), 217-226.

5. Aman, A. H. L., Harun, A., \& Hussein, Z. (2012). The Influence of Environmental Knowledge and Concern on Green Purchase Intention the Role of Attitude as a Mediating Variable. British Journal of Arts and Social Sciences, 7 (2), 145-167.

6. Ajzen, I., \& Fishbein, M. (1980). Understanding attitudes and predicting social behavior. Englewood Cliffs, NJ: Prentice-Hall.

7. Barber, N., Taylor, D. C., \& Deale, C. S. (2010). Wine tourism, environmental concerns, and purchase intention. Journal of Travel \& Tourism Marketing, 27 (2), 146-165.

8. Chan, R. Y. K. (2004). Consumer responses to environmental advertising in China. Marketing Intelligence \& Planning, 22 (4), 427 - 437.

9. Chen. (2013). A Study of Green Purchase Intention Comparing with Collectivistic (Chinese) and Individualistic (American) Consumers in Shanghai, China. Information Management and Business Review, 5 (7), 342-346.

10. Chen, T. B., \& Chai, L.T. (2010). Attitude towards the Environment and Green Products: Consumers Perspective. Management Science and Engineering, 4 (2), 27 - 39.

11. D'Souza, C., \& Taghian, M. (2005). Green advertising effects on attitude and choice of advertising theme. Asia Pacific Journal of Marketing and Logistics, 17 (3), 51-66.

12. Dagher, G. K., Itani, O., \& Kassar, A. N. (2015). The Impact of Environment Concern and Attitude on Green Purchasing Behavior: Gender as The Moderator. Contemporary Management Research, 11 (2), 179-206.

13. Delafrooz, N., Taleghani, M., \& Nouri, B. (2014). Effect of green marketing on consumer purchase behavior. QScience Connect, 5, 1-9.

14. Engel, J. F., Blackwell, R. D., \& Miniard, P. W. (1994). Perilaku Konsumen. Translated by F.X. Budiyanto. Jakarta: Binapura Aksara. 
15. Ghozali, I. (2005). Aplikasi Analisis Multivariate Dengan Program SPSS. Semarang: Badan Penerbit Universitas Diponegoro.

16. Ghozali, I. (2013). Aplikasi Analisis Multivariate dengan Program IBM SPSS 21. Semarang: Badan Penerbit Universitas Diponegoro.

17. Ginting, R. K., \& Ekawati, N. W. (2016). Pengaruh pengetahuan lingkungan terhadap niat membeli produk hijau pada merek "attack" dengan kepedulian lingkungan sebagai variabel mediasi. E-Jurnal Manajemen Unud, 5 (4), 2223-2249.

18. Hair, J. F., Black, W. C., Babin, B. J., \& Anderson, R. E. (2010). Multivariate Data Analysis: Global Edition, 7/E. New Jersey: Pearson Higher Education.

19. Haryanto, B., \& Budiman, S. (2014). The Role of Environmental Knowledge in Moderating the Consumer Behavioral Processes Toward the Green Products (Survey on the Green Product-mind in Indonesian). Society of Interdisciplinary Business Research, 4 (1).

20. Haytko, D. L., \& Matulich, E. (2008). Green Advertising and Environmentally Responsible Consumer Behaviors: Linkages Examined Journal of Management and Marketing Research, 1, 2-11.

21. Henning, O., \& Karlsson, S. (2011). Environmental attitudes and how they affect purchase intentions of environmentally friendly automobiles. Master Thesis in International Business School. Jönköping University.

22. Herman, L. E., Udayana, I. B. N., \& Farida, N. (2017). Young Generation and Environmental Friendly Awareness : The Impact of Green Advertising on Green Purchase Intention.

23. Julina. (2013). Determinan Perilaku Pembelian Ekologis dan Konsekuensinya Terhadap Lingkungan: Perspektif Konsumen di Kota Pekanbaru Berdasarkan Kolektivisme, Perhatian Terhadap Lingkungan, Efektivitas Konsumen, dan Kesediaan Membayar. Kutubkhanah Jurnal Penelitian Sosial Keagamaan, 16 (2), 115-126.

24. Karatu, V. M. H., \& Mat, N. K. N. (2014). A New Model of Green Purchase Intention and its Derivatives: Confirmatory Factor Analysis Validation of Constructs. Information Management and Business Review, 6 (5), 261-268.

25. Laksmi, A. D., \& Wardana, I. M. (2015). Peran sikap dalam memediasi pengaruh kesadaran lingkungan terhadap niat beli produk ramah lingkungan. E-Jurnal Manajemen Unud, 4 (7), 1902-1917.

26. Lee, K. (2009). Gender differences in Hong Kong adolescent consumers' green purchasing behavior. Journal of Consumer Marketing, 26 (2), 87-96.

27. Lee, K. (2010). The Green Purchase Behavior of Hong Kong Young Consumers: The Role of Peer Influence, Local Environmental Involvement, and Concrete Environmental Knowledge. Journal of International Consumer Marketing, 23 (1).

28. Leonidou, L. C., Leonidou, C. N., \& Kvasova, O. (2010). Antecedents And Outcomes Of Consumer Environmentally Friendly Attitudes And Behaviour. Journal of Marketing Management, 26 (13-14), 1319-1344. DOI: 10.1080/0267257X.2010.523710

29. Leonidou, L. C., Leonidou, C. N., Palihawadana, D., \& Hultman, M. (2011). Evaluating the green advertising practices of international firms: a trend analysis. International Marketing Review, 28 (1), 6-33.

30. Levine, D. S., \& Strube, M. J. (2012). Environmental Attitudes, Knowledge, Intentions and Behaviors Among College Students. The Journal of Social Psychology, 152 (3), 308-326.

31. Mei, O. J., Ling, K. C., \& Piew, T. H. (2012). The Antecedents of Green Purchase Intention among Malaysian Consumers. Asian Social Science, 8 (13), 248-263.

32. Morel, M., \& Kwakye, F. (2012). Green Marketing: Consumer's Attitudes towards EcoFriendly Products and Purchase Intention in the Fast Moving Consumer Goods (FMCG) Sector. Unpublished Thesis. Umeå School of Business.

33. Noor, N. A. M., Muhammad, A., Kassim, A., Jamil, C. Z. M., Mat, N., Mat, N., \& Salleh, H. S. (2012). Creating green consumers: how environmental knowledge and environmental attitude lead to green purchase behavior?. International Journal of Arts \& Sciences, 5 (1), 55-71. 
34. Paco, A. d., \& Raposo, M. (2009). "Green" segmentation: an application to the Portuguese consumer market. Marketing Intelligence \& Planning, 27 (3), 364-379.

35. Pallant, J. (2005). SPSS Survival Manual : a step by step guide to data analysis using SPSS for Windows

36. Peter, J. P., \& Olson, J. C. (2000). Consumer Behaviour : Perilaku Konsumen dan Strategi Pemasaran, jilid 1 dan jilid 2. Jakarta: Erlangga.

37. Peter, J. P., \& Olson, J. C. (2013). Perilaku Konsumen dan Strategi Pemasaran. Jakarta: Salemba Empat.

38. Prastiyo, Y. (2016). Pengaruh Green Marketing Tools terhadap Perilaku Pembelian Konsumen. E-Jurnal Manajemen Unud, 5 (6), 3449- 3475.

39. Rahbar, E., \& Wahid, N. A. (2011). Investigation of green marketing tools' effect on consumers' purchase behavior. Business Strategy Series, 12 (2),73-83.

40. Rashid, N. R. N. A. (2009). Awareness of Eco-label in Malaysia's Green Marketing Initiative International Journal of Business and Management, 4 (8), 132-141.

41. Riduwan \& Kuncoro, E. A. (2012). Cara Menggunakan dan Memakai Path Analysis (Analisis Jalur). Bandung: Alfabeta.

42. Rini, A. S., Giantari, I. G. A. K., \& Sukaatmadja, I. P. G. (2017). Pengaruh Pengetahuan Lingkungan Dan Kepedulian Lingkungan Terhadap Sikap Dan Niat Beli Poduk Hijau "THE BODY SHOP" Di Kota Denpasar. E-Jurnal Ekonomi dan Bisnis Universitas Udayana, 6 (1), 137-166.

43. Sumarsono, \& Giyatno, Y. (2012). Analisis sikap dan pengetahuan konsumen terhadap ecolabelling serta pengaruhnya pada keputusan pembelian produk ramah lingkungan. Performance, 15 (1), 70-85.

44. Suryandari, N. K. D., Suprapti, N. W. S., \& Sukaatmadja, I. P. G. (2016). Aplikasi theory of planned behavior (TPB) dalam menjelaskan perilaku ekologis generasi $Y$ di Kota Denpasar. Jurnal Manajemen, Strategi Bisnis dan Kewirausahaan, 10 (1).

45. Syahbandi. (2012). Implementasi Green Marketing Melalui Pendekatan Marketing MIX, Demografi Dan Pengetahuan Terhadap Pilihan Konsumen (Studi The Body Shop Pontianak). Jurnal Ekonomi, Bisnis dan Kewirausahaan, 3 (1), 68-86.

46. Tjiptono, F. (2005). Pemasaran Jasa. Malang: Bayumedia Publishing.

47. Wulandari, A. S. A., Rahyuda, I. K., \& Yasa, N. N. K. (2015). Peran sikap memediasi pengaruh pengetahuan konsumen terhadap niat beli produk hijau. Jurnal Dinamika Manajemen, 6 (2), 133-144.

48. Zhu, B. (2013). The Impact of Green Advertising on Consumer Purchase Intention of Green Products World Review of Business Research, 3 (3), 72 - 80. 